\title{
Az indonéz kormányzati szektor belsö kontrollrendszere és az önkormányzatok igazgatási teljesítményének kapcsolata
}

\author{
Jaka Winarna \\ Universitas Sebelas Maret Surakarta \\ jaka.winarna@staff.uns.ac.id \\ Muhtar Muhtar \\ Universitas Sebelas Maret Surakarta \\ muhtar@staff.uns.ac.id \\ Sutaryo Sutaryo \\ Universitas Sebelas Maret Surakarta \\ sutaryo@staff.uns.ac.id \\ Prihatnolo Gandhi Amidjaya \\ Universiti Malaysia Sarawak \\ prihatnologandhi@gmail.com
}

\begin{abstract}
Összefoglaló
A tanulmány az önkormányzati belső kontrollrendszereknek az önkormányzatok igazgatási teljesítményére gyakorolt hatását vizsgálja Indonézia példáján. A szerzők a Belügyminisztérium, a Pénzügyi és Fejlesztési Felügyelet, a Statisztikai Hivatal, valamint az önkormányzati pénzügyi beszámolók és weboldalak másodközlésű adatait használák fel. 508 önkormányzatnak a 2017-2019-es időszakra vonatkozó 1524 adatsorából adatbázist hoztak létre, és az adatok közötti összefüggéseket elemezték. A cikk bemutatja, hogy 2017-2019 között több önkormányzat még mindig alacsony vagy közepes igazgatási teljesítményt nyújtva működik, ami nem elégíti ki a Belügyminisztérium 2015. évi stratégiai tervében meghatározott elvárásokat. Elemzésünk empirikus bizonyítékot nyújt arra, hogy a belső kontrollrendszer három eleme: a kontrollkörnyezet, a kockázatelemzés, valamint az információ és kommunikáció pozitívan hat az önkormányzatok igazgatási teljesítményére. Eredményünk segítséget kíván nyújtani a Pénzügyi és Fejlesztési Felügyeletnek, hogy folyamatosan optimalizálja az indonéz önkormányzatok belső kontrollrendszerének fejlesztésére irányuló programjait, illetve a Belügyminisztériumnak, hogy nagyobb hatást gyakorolhasson az önkormányzatok igazgatási teljesítményére.
\end{abstract}

KuLcsszavaK: Indonézia, önkormányzat, igazgatási teljesítmény, belső kontrollrendszer JEL-кóрок: H11, H70, H83, M48

DOI: https://doi.org/10.35551/PSZ_2021_k_2_5 
Az indonéz önkormányzatok jelentős szerepet játszanak a közügyek igazgatásában (Sutopo, Wulandari, Adiati, Saputra, 2017), elsősorban a regionális autonómiának köszönhetően. A kormányzati teljesítmény egy olyan kérdés, amely folyamatosan reflektorfényben van Indonéziában. A Belügyminisztérium által képviselt központi kormányzat minden évben értékeli az önkormányzatok igazgatási teljesítményét. Az értékelés inputok, folyamatok, outputok, eredmények, hasznok és hatások mérése alapján ad megbízható képet az önkormányzatok igazgatási teljesítményéről. Az indonéz önkormányzatok egy részének teljesítménye még mindig nem felel meg a Belügyminisztérium elvárásainak. 2018-ig még mindig sok olyan önkormányzat volt, amely nem ért el magas szintű teljesítményt. ${ }^{1}$ Ez nem felel meg a Belügyminisztérium céljának, ${ }^{2}$ amely minden önkormányzattól legalább magas szintű teljesítményt vár el. Ezért nagyon fontos az olyan empirikus kutatás, amely átfogóan vizsgálja az önkormányzatok igazgatási teljesítményét, fóként annak meghatározó tényezőit, hogy a legjobb gyakorlatok eléréséhez szükséges szakpolitikai ajánlásokat lehessen megfogalmazni.

Az önkormányzati teljesítmény egyik leginkább meghatározó tényezője a belsőkontroll-rendszer (Benedek, Szenténé, Beres, 2014; Urbanik, 2016). Indonéziában a 2008. évi 60. számú kormányrendelet ${ }^{3}$ szabályozza az igazgatási szervek belső kontrollrendszerét, amelyet a COSO-modell 2013. évi változatának koncepcióját követve dolgoztak ki az átlátható és elszámoltatható pénzügyi irányítás megteremtése érdekében. A belső kontroll fontos szerepet játszik a szervezeti célok, köztük a teljesítménycélok megvalósításában (Gyüre, 2012). Ezt az összefüggést azonban a közszféra irányításának szakirodalma kevéssé tárta fel, föként nem empirikus kutatások alapján. A belső kontrollok szerepét vizsgáló több korábbi tanulmány megállapításai a közszférára csak korlátozásokkal érvényesek, mivel azok többsége a magánszektorra összpontosított (Dabbagoglu, 2012; Hillison, Pacini, Sinason, 1999). Sok tanulmány alacsony számú kutatási megfigyelésre támaszkodik (Liu, Lin, 2012; Sutopo, Wulandari, et al., 2017; Utama, Evana, Gamayuni, 2019). Ezért a szakirodalomban fellelhető tanulmányok nem adnak átfogó képet.

E tanulmány célja, hogy a gyakorlatban hasznosítható hozzájárulást adjon a belső kontrollrendszer fejlesztésére irányuló, a nyilvános elszámoltathatóságot javító ajánlások megfogalmazásához. A szerzők további célja az, hogy a belső kontrollrendszerek müködésének átfogó elemzésével, valamint annak az önkormányzatok igazgatási teljesítményére gyakorolt hatásainak feltárásával hozzájáruljanak a téma szakirodalmának gazdagításához.

\section{SZAKIRODALMI ÁTTEKINTÉS ÉS A HIPOTÉZISEK MEGFOGALMAZÁSA}

\section{Ügynökelmélet}

Jensen és Meckling (1976) megfogalmazása szerint a megbízó és az ügynök között ügynökségi kapcsolat áll fenn, ha az ügynök a megbízó nevében és javára jár el. Az ügynökelmélet szerint az ügynökök maximalizálják saját érdekeiket, de próbálják teljesíteni a megbízóval kötött szerződést (Mantysaari, 2009). Ebben az esetben az elszámoltathatóság annak bizonyítéka, hogy az ügynök felelös tetteiért. Hali és Abdullah (2006) szerint az ügynökelmélet az önkormányzatoknál is érvényes, ahol az önkormányzat nyilvános ügynökként jár el. $\mathrm{Ha}$ ez az önkormányzati elszámoltathatóság megvalósítására irányuló erőfeszítésekkel párosul, akkor az hozzájárul a megfelelő önkormányzati teljesítményhez. 


\section{Önkormányzati igazgatási teljesítmény}

A felhatalmazott félnek a többi félhez való felelős hozzáállásának az egyik legfontosabb szempontja a teljesítmény. A kormány felelős azért, hogy a közpénzekből nyújtott közszolgáltatásokat megfelelő színvonalon nyújtsák (Sari, Ghozali, Achmad, 2017). Az indonéz Belügyminisztérium - igazgatási teljesítménynyel kapcsolatos vélemények, folyamatok, eredmények, hasznok és hatások mérése alapján - évente végez teljesítményértékelést az önkormányzatoknál (LGPAE).

Az LGPAE-index alakulását egyaránt befolyásolja az önkormányzati igazgatási ügyek átfogó, a politikakészítéstől a megvalósítási szakaszig tartó értékelése, valamint a közszolgáltatások nyújtása és azok elsődleges megítélése (Sari et al., 2017). Az értékelés magában foglalja az igazgatási ügyek átfogó mutatóit az 1. ábrán látható módon. Minden mutatót kiértékelnek, a végső értékelési pontszám 1-től 4-ig terjed (1=alacsony; 2=közepes; 3=magas; $4=$ nagyon magas). A Belügyminisztérium a 2009. évi 73. számú belügyminiszteri rendelettel nyilvánosságra hozta a Belügyminisztérium 2015-2019 időtávú stratégiai tervét. A rendelet azt tűzi ki célul, hogy minden indonéz önkormányzat legalább magas (3. szintű) igazgatási teljesítményt érjen el 2017-re.

\section{A kormányzati szektor belső kontrollrendszere}

A COSO (2013) koncepciója szerint a belső kontrollrendszer a szervezet által végrehajtott folyamat, amelynek célja a működés hatékonyságának és eredményességének, a pénzügyi beszámolás megbízhatóságának, valamint az alkalmazandó jogszabályoknak való megfelelés biztosítása. Az indonéz kormány több fontos változtatást vezetett be az állami irányításban az 1998-as reform óta, az egyik a kormányzati szek- tor belső kontrollrendszerének (SPIP) létrehozása a 2008. évi 60. kormányrendeletben meghatározott módon, amelyet a kormányzati szektorba tartozó intézmények kötelesek alkalmazni központi és önkormányzati szinten egyaránt.

A kormányzati szektor belső kontrollrendszere annak bizonyítéka, hogy a kormány elkötelezett a nyilvános elszámoltathatóság mellett, amelyben az előrelépést a COSO koncepciójának adaptálása jelentette. A COSOkeretrendszer adaptációja a belső kontrollrendszer fejlesztésére összhangban van a nemzetközi fejleményekkel, mivel a keretrendszert több ország elfogadta, általános érvényességét pedig tudósok is alátámasztják (Benedek et al., 2014). A COSO-keretrendszer célja ésszerü biztosítékok nyújtása arról, hogy a kormányzati szektorba tartozó szervezet tevékenységének megszervezése képes biztosítani a célok eredményes és hatékony megvalósítását, a pénzügyi irányítás és beszámolás megbízhatóságát, a vagyonbiztonságot, valamint a törvényeknek és rendeleteknek való megfelelést. Hatékony belső kontrollrendszerrel felelős és átlátható közpénzügyi irányítás érhető el. Ezzel szemben a belső kontroll hiányosságai gyenge irányítást eredményeznek (Rácz, Tóth, 2021). Erre tekintettel a belső kontrollrendszer fejlesztését komolyan kell venni, valamint a kormányzati reformok során magas prioritását kell élveznie (Urbanik, 2016). A COSO keretrendszerrel összhangban a kormányzati szektor belső kontrollrendszerének (SPIP) elemei a következők: kontrollkörnyezet, kockázatelemzés, kontrolltevékenységek, információ és kommunikáció, monitoring.

A kormányzati szektor belső kontrollrendszerének megvalósítását minden évben a Pénzügyi és Fejlesztési Felügyelet (BPKP) és a Legfelsőbb Számvevői Testület (BPK) értékeli. A BPKP évente végez értékelést a kormányzati belső kontrollrendszer érettségéről, hogy felmérje, mennyire jól teljesít a rendszer, és menynyire fejlett az egyes kormányzati szektorba tartozó intézményekben. Ez az értékelés álla- 
1. ábra

\section{A TELJESÍTMÉNY ÖSSZETETT INDEXÉNEK SÚLYOZÁSA}

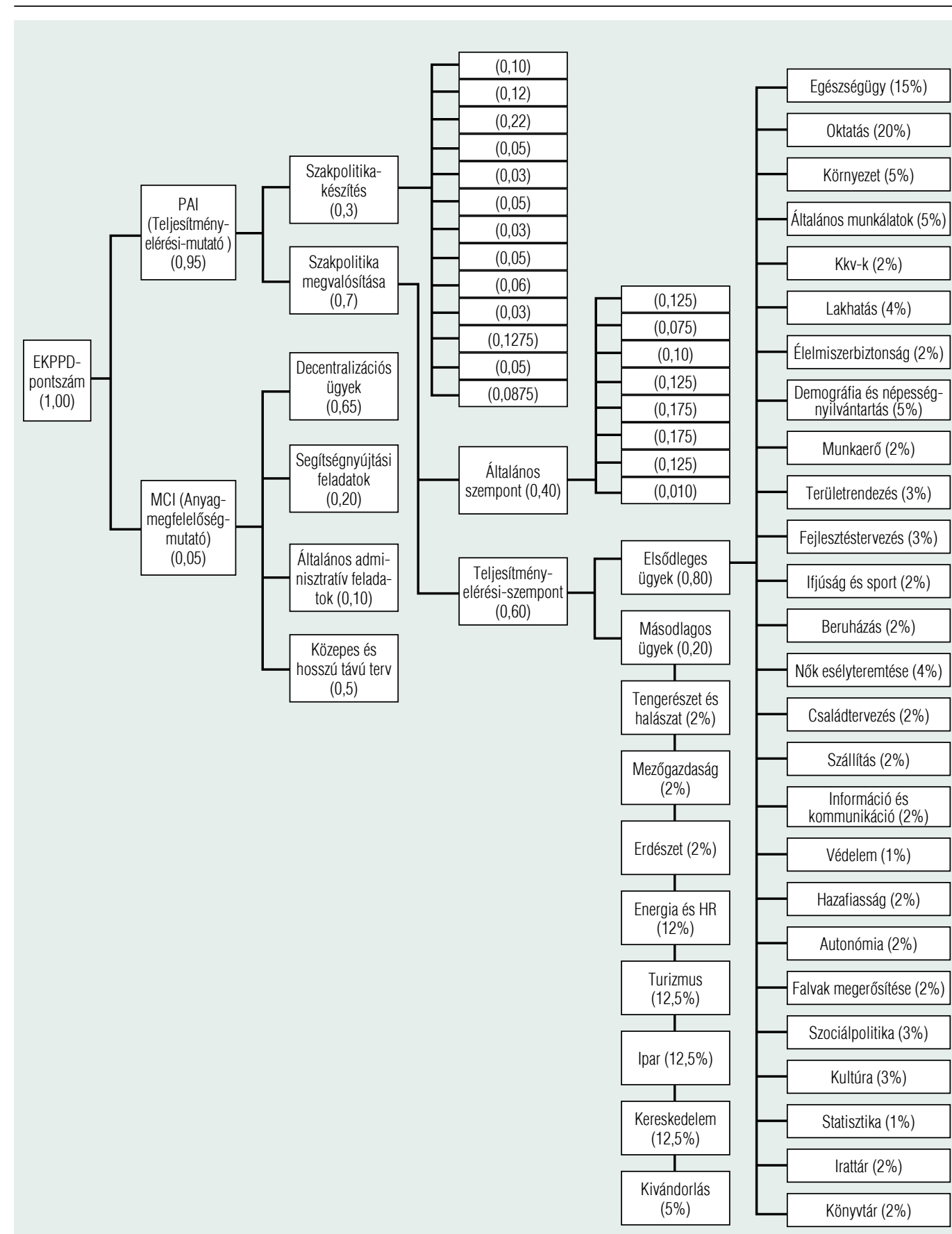

Forrás: Önkormányzati igazgatási teljesítményértékelés (LGAPE) kézikönyv előirásai ${ }^{4}$ 
pítja meg a belső kontrollrendszer érettségét. Mindeközben a BPK is évente vizsgálja a kormányzati belső kontrollrendszert a kormányzati szektorba tartozó intézmények pénzügyi beszámolói auditálásának részeként. A BPK megállapítja a kormányzati belső kontrollrendszer gyengeségeit, valamint ajánlásokat tesz azok javítására. Ezért az értékelések és vizsgálatok révén a kormányzati belső kontrollrendszer megvalósítása az indonéz kormányzati intézményekben folyamatosan javulhat a megfelelő irányítás és elszámoltathatóság érdekében.

\section{Kontrollkörnyezet és önkormányzati igazgatási teljesítmény}

A kontrollkörnyezet - amely magában foglal többek között értékeket, etikát, integritást, személyzeti politikát és szervezeti felépítést (COSO 2013) - hatással van a szervezet dolgozóinak a magatartására (Rubino, Vitolla, Garzoni, 2017). A motiváló kontrollkörnyezettel rendelkező önkormányzatok programjaikat és tevékenységeiket a tervek szerint és költségvetésük betartása mellett tudják végrehajtani, így teljesítményük eredményes és elszámoltatható marad, ami a számvevőszéki ellenőrzések elsődleges kulcskritériuma (Jones, 2008). Megfelelő kontrollkörnyezettel az önkormányzati igazgatás magas teljesítményt érhet el. A leírtak alapján a hipotézist a következőképpen fogalmazzuk meg.

$\mathrm{H}_{1}$ : A kontrollkörnyezet pozitívan hat az önkormányzati igazgatási teljesítményre

\section{Kockázatértékelés és önkormányzati igazgatási teljesítmény}

A kockázatok megléte lehetőségeket nyújt a bevett normáktól eltérő cselekedetekre, föként az önkormányzatok pénzügyi irányítá- sának területén, amit a kockázatok olyan növekedése követ, amelyeknek nincsenek is feltétlenül a tudatában (Shanmugam et al., 2012). Így szükség van a kockázatértékelésre (Dabbagoglu, 2012), azaz a kockázatok azonosítására, értékelésére és kezelésére (Jones, 2008). Rendon, Rendon (2016) szerint a csalás kockázatai veszélyeztethetik a szervezeti elszámoltathatóságot, főleg ha a csalás nyilvánosságra kerül, ezáltal csorbítva a szervezet jó hírnevét. Ezért a megfelelő kockázatértékelés megléte minden önkormányzati tevékenységben elengedhetetlen, függetlenül attól, hogy a kockázat jelentős-e vagy sem. A kockázatértékelés a közintézmények irányításban is fontos (Wardhani, Rossieta, Martani, 2017). Báger (2011) azt is ajánlja, hogy a kockázat feltérképezését a közszférában még szélesebb körben alkalmazzák. Ezért a COSO (2013) koncepcióját követve arra számíthatunk, hogy a kockázatértékelés az önkormányzati igazgatás magas teljesítményét eredményezheti Az előzőek alapján így hangzik a hipotézis:

$\mathrm{H}_{2}$ : A kockázatértékelés pozitívan hat az önkormányzati igazgatási teljesítményre

\section{Kontrolltevékenységek}

és önkormányzati igazgatási teljesítmény

A kontrolltevékenységeknek a fizikai kontrollokon, a teljesítmény jelentésén és a felelősségi körök elhatárolásán keresztül biztosítaniuk kell, hogy a a célok megvalósítását szolgáló tevékenységek megfelelően legyenek végrehajtva (Rendon, Rendon, 2016). A kontrolltevékenységek elengedhetetlenek a teljesítmény javításához (Al-Thuneibat, Al-Regaily, Basodan, 2015). Kontrolltevékenységek kellenek az eljárások és a szakpolitikák végrehajtásának biztosításához is (Mandzila, Zéghal, 2016). Lényegében a kontrolltevékenységek több olyan tevékenységet is magukban fog- 
lalnak, amelyek összevetik azt, ami éppen történik, és aminek történnie kellene ideális körülmények között, elvárva az optimális eredmények elérését. Így az erőforrás-kezelés optimális lesz, és az önkormányzatok magas igazgatási teljesítménye valószínűsíthető (Koutoupis, 2012). Hipotézisünk a következőképpen hangzik:

$\mathrm{H}_{3}$ : A kontrolltevékenységek pozitívan hatnak az önkormányzati igazgatási teljesítményre

Információ és kommunikáció, valamint az önkormányzati igazgatási teljesítmény

Az információ és kommunikáció elengedhetetlen a szervezeti tevékenységek megvalósítása során (Al-Thuneibat et al., 2015), főleg a döntéshozatalban (Naser, Al Shobaki, Ammar, 2017). Megfelelő információval és kommunikációval megakadályozható a jogosulatlan személyek hozzáférése erőforrásokhoz (Lestari et al., 2019). A jobb információ és kommunikáció megfelelő tervezést és így később optimális eredményeket hoz, így az önkormányzatok igazgatási teljesítménye várhatóan magas színvonalú lesz. Mi több az információ- és kommunikációáramlás betartandó jogi keretként szabályzatba is foglalható. Amikor egy adott szabályozást megfelelően kommunikálnak és gyakorolnak, az elvárt teljesítmény elérhető lesz. Ezzel szemben, amikor egy alapvető szabályozást nem megfelelően kommunikálnak és a jogi keretrendszer túl gyenge, az teljesítménybeli és irányítási problémákat eredményezhet (Melly, 2011). Így a hipotézisünk a következőképpen hangzik:

$\mathrm{H}_{4}$ : Az információ és kommunikáció pozitívan hat az önkormányzati igazgatási teljesítményre
Monitoring és önkormányzati igazgatási teljesítmény

A monitoring segít a szervezetnek, hogy folyamatosan nyomon kövesse a belső kontrollok minőségét, és így elérhetők legyenek a szervezeti célok (Rendon, Rendon, 2016). Petrakaki, Hayes, Introna (2009) a megfigyelés monitoringhatásait e-kormányzati technológia segítségével vizsgálták, és úgy találták, hogy a monitoring pozitív hatással van a közszolgáltatás elszámoltathatóságára. A monitoring lehetővé teszi, hogy következetes haladással érjék el a teljesítményre vonatkozó célokat (Lestari et al., 2019). Ezért az optimális monitoring javít a teljesítményen és elszámoltathatóságon (Kiabel, 2012). Az összegzett szakirodalom alapján így hangzik a hipotézis:

$\mathrm{H}_{5}$ : A monitoring pozitívan hat az önkormányzati igazgatási teljesítményre

\section{KUTATÁSI MÓDSZERTAN}

\section{Sokaság, minták és kutatási adatok}

A kutatásban a sokaság az összes indonéz önkormányzat 2017-2019. évi adatai alkották. Az önkormányzatok ebben az időszakban elért teljesítményét annak a belügyminisztériumi célkitűzésnek a fényében vizsgáljuk, hogy 2017-től minden önkormányzat legalább „magas színvonalon” teljesítsen. Ez a kutatás a teljes sokaságot vizsgálja, annak érdekében, hogy átfogó kutatást végezzen és általánosítható megállapításokra jusson. Ez a tanulmány az érintett kormányzati szervektől - például Belügyminisztériumtól, a BPK-tól, a BPKP-tól, az indonéz Statisztikai Hivataltól (BPS) és a vonatkozó önkormányzati weboldalról - szerzett másodközlésű adatokat használta fel. Végül ez a kutatás 1524 megfigyelésből álló adat- 
bázist állított össze 508 indonéz kerületi/városi önkormányzattól, a 2017-2019-es évekből származó adatokból.

\section{Kutatási változók}

A kutatásban az önkormányzati igazgatási teljesítményt tekintettük függő változónak, amelyet a Belügyminisztérium által közzétett önkormányzati igazgatási teljesítményértékelés értékelési pontszámával mértünk. A független változók pedig, a kormányzati belső kontrollrendszer elemei, azaz a kontrollkörnyezet, a kockázatelemzés, a kontrolltevékenységek, információ és kommunikáció, valamint a monitoring voltak. A pontszámot a BPKPönkormányzatok belső kontrollrendszeréről szóló beszámolója hivatalos értékeléséből vettük át. Minden változót a Pénzügyi és Fejlesztési Felügyelet vezetőjének 2016. évi 4. számú rendeletében szabályozott mutatók alapján értékeltünk. ${ }^{5}$ Továbbá ez a tanulmány több kontrollváltozót is alkalmaz a független változókon kívül eső tényezők figyelembevétele érdekében. A kutatási változókat és a mérésük módját az 1. táblázat összegzi.

\section{Adatelemzés}

A tanulmányunk kezdeti elemzését leíró statisztikával végeztük, kutatási adatainkat egyváltozós elemzéssel mutatjuk be, amely gyakorisági eloszlást, átlag-, minimum- és maximumértéket, valamint standardeltérésértéket tartalmaz. A változó korrelációt is ellenőrizzük Pearson-korreláció vizsgálattal. A feltevés vizsgálatának fö elemzését illetően paneladat-visszafejlődési elemzést alkalmazunk. Az általános regressziós modellünk az következők szerint néz ki:

$\mathrm{LGAP}_{i, t}=\alpha+\beta_{1} \mathrm{CO}_{-} \mathrm{ENV}_{i, t}+\beta_{2} \mathrm{RISK}_{i, t}+$ $\beta_{3} \mathrm{CO} \_\mathrm{ACTIV}_{i, t}+\beta_{4} \mathrm{INFO}_{i, t}+\beta_{5} \mathrm{MONI}_{i, t}+$ $\beta_{6} \mathrm{LN}_{-} \mathrm{LGASSET}{ }_{i, t}+\beta_{7} \mathrm{LN}_{-} \mathrm{LGREV}{ }_{i, t}+\beta_{8} \mathrm{LN}$ LGEXPEND $_{i, t}+\beta_{9} \mathrm{LGPOP}_{i, t}+\beta_{10} \mathrm{LGCOM}_{i, t}+$ $\beta_{11} \mathrm{LGGEO}_{i, t}+\beta_{12} \mathrm{LGTYPE}_{i, t}+e$

Jelmagyarázat:

$\alpha:$ konstans

$\beta_{1} \ldots \beta_{12}$ : regressziós együtthatók

LGAP $_{i, t}$ : önkormányzati igazgatási teljesítmény

$\mathrm{CO} \_E N V_{i, t}$ : kontrollkörnyezet

RISK $_{i, t}$ : kockázatértékelés

CO_ACTIV ${ }_{i, t}:$ kontrolltevékenységek

$\mathrm{INFO}_{i, t}$ : információ és kommunikáció

$\mathrm{MONI}_{i, t}$ : monitoring

LN_LGASSET $_{i, t}$ : önkormányzati vagyon

LN_LGREV ${ }_{i, t}$ : önkormányzati bevétel

LN_LGEXPEND $_{i, t}$ : önkormányzati kiadás

LGPOP $_{i, t}$ : önkormányzat népessége

LGCOM $_{i, t}$ : önkormányzat komplexitása

$\mathrm{LGGEO}_{i, t}$ : önkormányzati földrajzi fekvése

LGTYPE $_{i, t}$ : önkormányzat típusa

$e:$ standard hiba

\section{EREDMÉNY ÉS TÁRGYALÁS}

\section{Statisztikai leíró jellemzés}

Elemzésünket a statisztikai jellemzők ismertetésével kezdjük, hogy kutatási adataink általános összegzést nyerjünk. 2017-2019-ben az átlagos önkormányzati igazgatási teljesítmény 3,449, ami „nagyon magas szintu”” teljesítménynek minősül. A maximális eredmény 4-es szintü, 'nagyon magas', a legalacsonyabb pedig az 1. szint, 'alacsony' teljesítmény. A leíró statisztikát a 2. táblázat mutatja.

A független változóink vizsgálata követi a BPKP vezetőjének 2016. évi 4. számú rendeletében meghatározott a belső kontrollrendszer értékelésre vonatkozó iránymutatásokat ${ }^{6}$ annak megállapításához, hogy mennyire jól valósítják meg az önkormányzatok a változókat. Az iránymutatások alapján a belső kont- 


\section{A KUTATÁSI VÁLTOZÓK OPERATÍV MEGHATÁROZÁSA}

\begin{tabular}{|c|c|c|c|}
\hline Változó & Jelölés & Mérés & Referenciák \\
\hline \multicolumn{4}{|l|}{ Fitggö } \\
\hline $\begin{array}{l}\text { Önkormányzati igaz- } \\
\text { gatási teljesítmény }\end{array}$ & $\operatorname{LGAP}_{i, t}$ & $\begin{array}{l}\text { A Belügyminisztérium által közzétett önkormányza- } \\
\text { ti igazgatási teljesítmény szintjének értékelési pont- } \\
\text { száma }\end{array}$ & $\begin{array}{l}\text { Sutopo et al. (2017), } \\
\text { Utama et al. (2019) }\end{array}$ \\
\hline \multicolumn{4}{|l|}{ Figgetlen } \\
\hline Kontrollkörnyezet & CO_ENV ${ }_{i, t}$ & $\begin{array}{l}\text { A Pénzügyi és Fejlesztési Felügyelet értékelési } \\
\text { pontrendszere az alábbi mutatókat tartalmazza: } \\
\text { a) Integritás és etika } \\
\text { b) Kompetencia melletti elköteleződés } \\
\text { c) Motiváló vezetés } \\
\text { d) Szervezeti felépítés } \\
\text { e) Felhatalmazás és felelősség elosztása } \\
\text { f) Humánerőforrás-politika } \\
\text { g) Belső felügyeleti szerepkör hatékonysága } \\
\text { h) Szakmai munkakapcsolat } \\
\text { Az ellenőrzési környezet maximális pontszáma 1,5 }\end{array}$ & $\begin{array}{l}\text { COSO (2013), pénzügyi } \\
\text { és fejlesztési felügyeleti } \\
\text { ügynökség (2016) }\end{array}$ \\
\hline Kockázatértékelés & $\mathrm{RISK}_{i, t}$ & $\begin{array}{l}\text { A Pénzügyi és Fejlesztési Felügyelet értékelési } \\
\text { pontrendszere az alábbi mutatókat tartalmazza: } \\
\text { a) Kockázatazonositás } \\
\text { b) Kockázatértékelés } \\
\text { A kockázatértékelés maximális pontszáma } 1\end{array}$ & $\begin{array}{l}\text { COSO (2013), pénzügyi } \\
\text { és fejlesztési felügyeleti } \\
\text { ügynökség (2016) }\end{array}$ \\
\hline $\begin{array}{l}\text { Kontrolltevékeny- } \\
\text { ségek }\end{array}$ & CO_ACTIV ${ }_{i, t}$ & $\begin{array}{l}\text { A Pénzügyi és Fejlesztési Felügyelet értékelési } \\
\text { pontrendszere az alábbi mutatókat tartalmazza: } \\
\text { a) Teljesítményértékelés } \\
\text { b) Humánerő́forrás-fejlódés } \\
\text { c) Információs rendszer megvalósítása } \\
\text { d) Fizikai kontroll a vagyon fölött } \\
\text { e) Ellenőrzési mutatók áttekintése } \\
\text { f) Feladatok szétválasztása } \\
\text { g) Meghatalmazás } \\
\text { h) Rögzítés } \\
\text { i) Hozzáférési politika } \\
\text { j) Elszámoltathatósági mechanizmus } \\
\text { k) Dokumentáció } \\
\text { A kontrolltevékenységek maximális pontszáma 1,25 }\end{array}$ & $\begin{array}{l}\text { COSO (2013), pénzügyi } \\
\text { és fejlesztési felügyeleti } \\
\text { ügynökség (2016) }\end{array}$ \\
\hline
\end{tabular}




\begin{tabular}{|c|c|c|c|}
\hline Változó & Jelölés & Mérés & Referenciák \\
\hline $\begin{array}{l}\text { Információ és kom- } \\
\text { munikáció }\end{array}$ & $\mathrm{INFO}_{i, t}$ & $\begin{array}{l}\text { A Pénzügyi és Fejlesztési Felügyelet értékelési } \\
\text { pontrendszere az alábbi mutatókat tartalmazza: } \\
\text { a) Információ } \\
\text { b) Kommunikáció hatékonysága } \\
\text { Az információ és kommunikáció maximális pont- } \\
\text { száma 0,5 }\end{array}$ & $\begin{array}{l}\text { COSO (2013), Pénzügyi } \\
\text { és Fejlesztési Felügye- } \\
\text { let (2016) }\end{array}$ \\
\hline Monitoring & $\mathrm{MONI}_{i, t}$ & $\begin{array}{l}\text { A Pénzügyi és Fejlesztési Felügyelet értékelési } \\
\text { pontrendszere az alábbi mutatókat tartalmazza: } \\
\text { a) Folyamatos monitoring } \\
\text { b) Különválasztott értékelés } \\
\text { A monitoring maximális pontszáma 0,75 }\end{array}$ & $\begin{array}{l}\text { COSO (2013), Pénzügyi } \\
\text { és Fejlesztési felügye- } \\
\text { let (2016) }\end{array}$ \\
\hline \multicolumn{4}{|l|}{ Kontrollváltozók } \\
\hline $\begin{array}{l}\text { Helyi önkormányza- } \\
\text { tok eszközei }\end{array}$ & LGASSET $_{i, t}$ & $\begin{array}{l}\text { A helyi önkormányzatok eszközeinek természetes } \\
\text { logaritmusa }\end{array}$ & $\begin{array}{l}\text { Sutaryo, Sinaga (2018), } \\
\text { Utama et al. (2019) }\end{array}$ \\
\hline $\begin{array}{l}\text { Helyi önkormányza- } \\
\text { tok bevételi }\end{array}$ & LGREV $_{i, t}$ & $\begin{array}{l}\text { A helyi önkormányzatok bevételeinek természetes } \\
\text { logaritmusa }\end{array}$ & $\begin{array}{l}\text { Sutaryo, Sinaga (2018), } \\
\text { Utama et al. (2019) }\end{array}$ \\
\hline $\begin{array}{l}\text { Helyi önkormányza- } \\
\text { tok kiadásai }\end{array}$ & LGEXPEND $_{i, t}$ & $\begin{array}{l}\text { A helyi önkormányzatok kiadásainak természetes } \\
\text { logaritmusa }\end{array}$ & $\begin{array}{l}\text { Sutaryo, Sinaga (2018), } \\
\text { Utama et al. (2019) }\end{array}$ \\
\hline $\begin{array}{l}\text { Önkormányzatok } \\
\text { népessége }\end{array}$ & $\mathrm{LGPOP}_{i, t}$ & A teljes népesség természetes logaritmusa & Rakhman (2019) \\
\hline $\begin{array}{l}\text { Önkormányzatok } \\
\text { komplexitása }\end{array}$ & $\operatorname{LGCOM}_{i, t}$ & $\begin{array}{l}\text { Az önkormányzatok szervezeti egységeinek teljes } \\
\text { száma }\end{array}$ & Adiputra, et al. (2018) \\
\hline $\begin{array}{l}\text { Önkormányzatok } \\
\text { földrajzi fekvése }\end{array}$ & $\mathrm{LGGEO}_{i, t}$ & $\begin{array}{l}\text { Képzett változó: } \\
0 \text { = Jáván kívül eső önkormányzatok } \\
1 \text { = Jávában található önkormányzatok }\end{array}$ & $\begin{array}{l}\text { Arifin, et al. (2015), } \\
\text { Rakhman, (2019) }\end{array}$ \\
\hline $\begin{array}{l}\text { Önkormányzati } \\
\text { típusok }\end{array}$ & $\operatorname{LGTYPE}_{i, t}$ & $\begin{array}{l}\text { Képzett változó: } \\
0=\text { kerületi önkormányzat } \\
1 \text { = városi önkormányzat } \\
2 \text { = tartományi önkormányzat }\end{array}$ & $\begin{array}{l}\text { Arifin, et al. (2015), } \\
\text { Rakhman (2019) }\end{array}$ \\
\hline
\end{tabular}

Forrás: saját szerkesztés

rollrendszer elemeinek maximális pontszáma a következő: kontrollkörnyezet $=1,5$; kockázatértékelés $=1$; kontrolltevékenységek $=1,25$; információ és kommunikáció $=0,5$; monitoring $=0,75$. Ezen változók összpontszáma határozza majd meg az önkormányzati belső kontrollrendszerének érettségét.
A kontrollkörnyezet átlagértéke 0,609. Így átlagosan az önkormányzatok a kontrollkörnyezet értékelési kritériumainak 40,6 százalékát teljesítik. A maximumérték 1,275, ami azt jelenti, hogy a 1 kontrollkörnyezet legmagasabb eredménye eléri a 85 százalékot, a minimumérték pedig 0,05, ami azt jelenti, hogy 


\section{LEÍRÓ STATISZTIKA}

\begin{tabular}{|c|c|c|c|c|c|}
\hline \multicolumn{6}{|c|}{ A PANEL: FOLYAMATOS VÁLTOZÓK } \\
\hline Változó & Megfigyelés & Átlag & Szórás & Minimum & Maximum \\
\hline $\operatorname{LGAP}_{i, t}$ & 1524 & 3,449 & 0,555 & 1,000 & 4,000 \\
\hline CO_ENV ${ }_{i, t}$ & 1524 & 0,609 & 0,218 & 0,050 & 1,275 \\
\hline $\mathrm{RISK}_{i, t}$ & 1524 & 0,191 & 0,211 & 0,000 & 0,800 \\
\hline CO_ACTIV ${ }_{i, t}$ & 1524 & 0,537 & 0,176 & 0,000 & 1,114 \\
\hline $\mathrm{INFO}_{i, t}$ & 1524 & 0,169 & 0,097 & 0,000 & 0,500 \\
\hline $\mathrm{MONI}_{i, t}$ & 1524 & 0,235 & 0,147 & 0,000 & 0,675 \\
\hline $\mathrm{LGPOP}_{i, t}$ & 1524 & 12,618 & 0,997 & 9,523 & 15,266 \\
\hline $\operatorname{LGCOM}_{i, t}$ & 1524 & 51,012 & 21,329 & 23,000 & 209,000 \\
\hline LGASSET $_{i, t}$ & 1524 & 28,537 & 0,613 & 27,096 & 31,387 \\
\hline LGREV $_{i, t}$ & 1524 & 27,927 & 0,499 & 24,484 & 29,801 \\
\hline LGEXPEND $_{i, t}$ & 1524 & 27,847 & 0,508 & 26,779 & 29,883 \\
\hline
\end{tabular}

\section{B PANEL: KÉPZETT VÁLTOZÓK}

\begin{tabular}{r|c|c|c|c|c|}
\hline \multirow{2}{*}{ Változó } & \multirow{2}{*}{ Megfigyelés } & \multicolumn{2}{|c|}{ Képzett 0 } & \multicolumn{2}{c|}{ Képzett 1 } \\
\cline { 3 - 6 } & & Gyakoriság & Százalé́k & Gyakoriság & Száralék \\
\hline LGGEO $_{i, t}$ & 1524 & 1158 & $76,0 \%$ & 366 & $24,0 \%$ \\
\hline LGTYPE $_{i, t}$ & 1524 & 1245 & $81,7 \%$ & 279 & $18,3 \%$ \\
\hline
\end{tabular}

Forrás: saját szerkesztés

a legrosszabb értékelési pontszám csupán az értékelési kritérium 3,33 százalékát érte el. A kockázatértékelés 0,191 átlagértéket mutat, ami a pontszámítási mutatók csupán 19,1 százalékát éri el, 0,8-as maximum pontszámmal, ami a kockázatértékelési kritériumok 80 százalékát teljesíti. A kontrolltevékenységek vonatkozásában az átlag 0,537, ami az értékelési kritériumok 42,96 százalékát éri el. Az 1,114es legmagasabb pontszámú teljesítmény az értékelési kritériumok 89,12 százalékának felel meg. Az információ és kommunikáció átlagos értéke 0,169 , ami az összes kritérium 33,8 százalékának felel meg, míg a legnagyobb ered- mény eléri a 0,5-öt, amely teljesen megfelel minden értékelési mutatónak. Végül a monitoring átlagértéke 0,235 (az értékelési mutatók 31,3 százalékát fedi le) 0,675-ös maximumértékkel (az értékelési mutatók 90 százalékát fedi le). A kockázatelemzés, a kontrolltevékenységek, az információ és kommunikáció, valamint a monitoring legalacsonyabb pontszáma 0 , ami azt jelenti, hogy a megvalósítás nem felelt meg az értékelési kritériumoknak.

Mélyrehatóbb leíróstatisztikai elemzést is végeztünk, megvizsgálva az önkormányzati igazgatási teljesítmény trendjét a megfigyelési időszakban, földrajzi elhelyezkedés szerint. 


\section{ÖNKORMÁNYZATI IGAZGATÁSI TELJESÍTMÉNY INDONÉZIÁBAN 2017-2019-BEN}

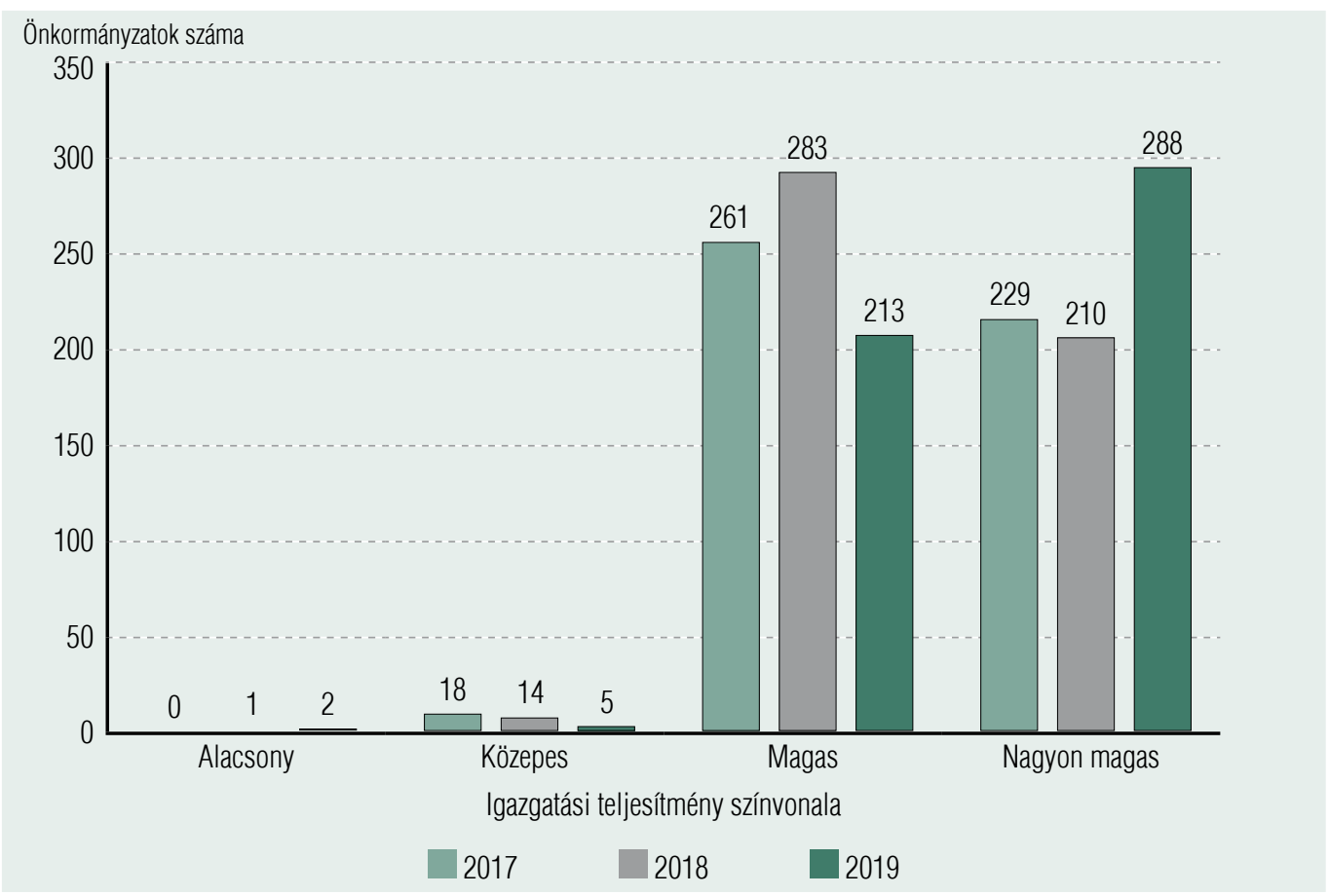

Forrás: saját szerkesztés az Indonéziai Köztársaság Belügyminisztériumának adatai alapján

Ahogyan az a 2. ábrán látható, az elemzés feltárta, hogy a legtöbb indonéz önkormányzat magas, illetve nagyon magas igazgatási teljesítményt tudott elérni 2017-2019-ben. Ami a teljesítmény elérését illeti, több az emelkedés, mint a csökkenés a megfigyelési időszakban. A magas és nagyon magas teljesítményszintű önkormányzatok száma összességében emelkedik; 2017-ben 490 önkormányzat (261 magas, 229 nagyon magas), 2018-ban 493 önkormányzat (283 magas, 210 nagyon magas), és 2019-ben 501 önkormányzat (213 magas, 288 nagyon magas) a stratégiai elvárásnak megfelelő minősítést ért el.

A közepes igazgatási teljesítményi eredménnyel rendelkező önkormányzatok tekintetében csökkenést tapasztaltunk, összhangban a magas és nagyon magas minősítések számának emelkedésével. 18 közepes teljesítményü önkormányzat volt 2017-ben, 14 önkormányzat 2018-ban és öt 2019-ben. Sajnos voltak alacsony teljesítményü önkormányzatok is: 1 önkormányzat 2018-ban és 2 önkormányzat 2019-ben. Ezen az eredményen javítani kell a Belügyminisztérium által kitűzött cél teljesítéséhez, amely elvárja, hogy az összes önkormányzat legalább magas teljesítményi szintet érjen el.

A földrajzi elhelyezkedés szerinti elemzés eredménye a 3. ábrán látható. Az eredmény azt mutatja, hogy a jávai és bali önkormányzatok rendelkeztek a legmagasabb igazgatási teljesítménnyel a megfigyelési időszakban. Az összes jávai és bali önkormányzat magas vagy nagyon magas igazgatási teljesítményt tudott elérni. A nagyon magas teljesítménnyel rendelkező önkormányzatok aránya eléri a 84 százalékot, amely a legmagasabb a többi földrajzi terület- 


\section{ÖNKORMÁNYZATI IGAZGATÁSI TELJESÍTMÉNY INDONÉZIÁBAN FÖLDRAJZI TERÖLET SZERINT}

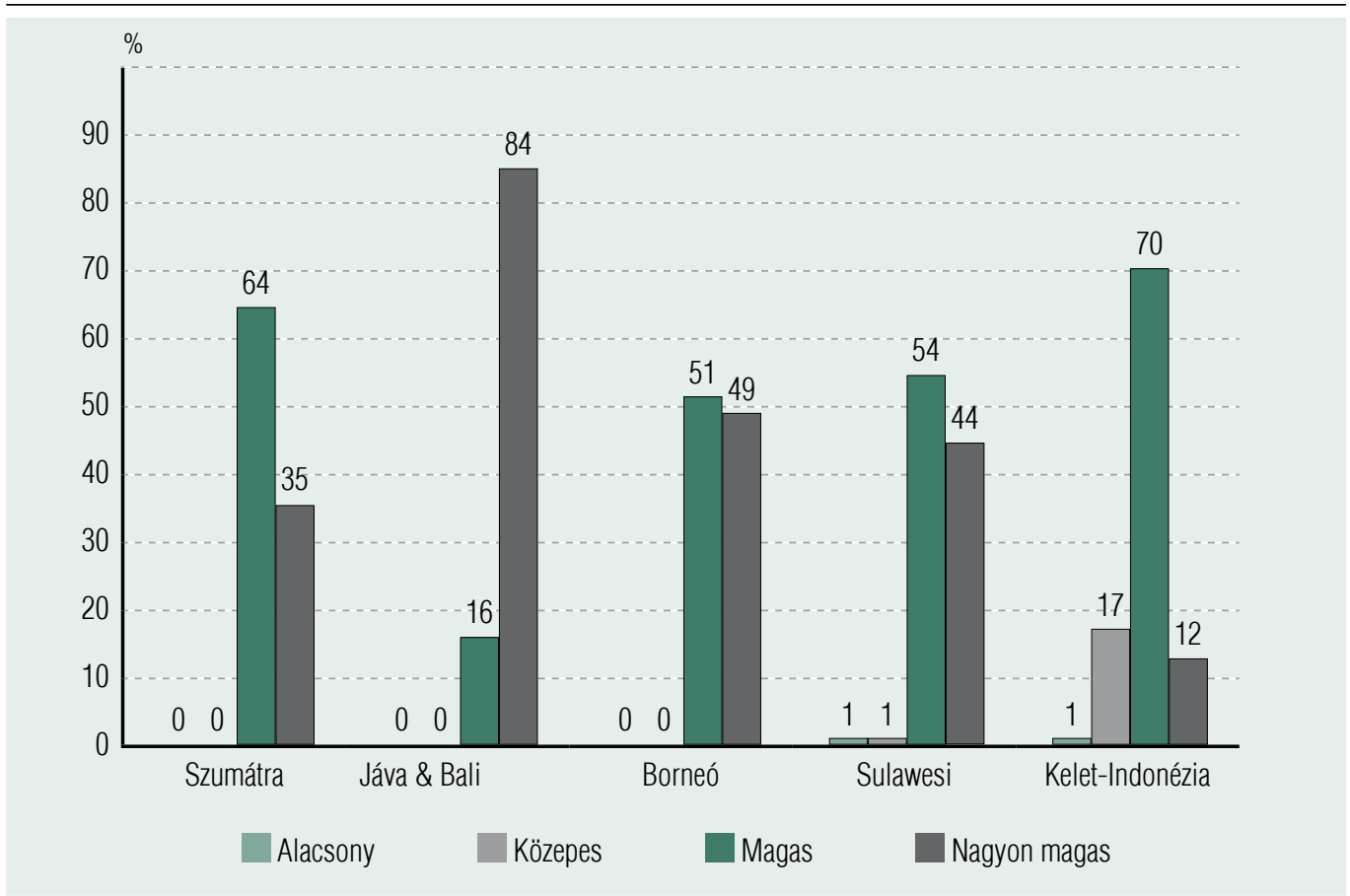

Forrás: saját szerkesztés az Indonéziai Köztársaság Belügyminisztériumának adatai alapján

hez képest. A borneói önkormányzatok rendelkeznek a második legjobb eredménnyel, az önkormányzatok 51 százaléka magas teljesítményü, 49 százaléka pedig nagyon magas teljesítményü. Szumátrán minden önkormányzat magas vagy nagyon magas igazgatási teljesítménnyel rendelkezik; 64 százalékuk magas, 35 százalékuk nagyon magas. A celebeszi önkormányzatok következnek, 54 százalékuk magas, 44 százalékuk nagyon magas teljesítménnyel bír, ugyanakkor az önkormányzatok 1 százaléka még mindig alacsony és közepes teljesítményü. A kelet-indonéz önkormányzatok sajnos még mindig jelentős fejlesztésre szorulnak. Az ottani önkormányzatok 1 százaléka alacsony, 17 százaléka pedig közepes teljesítményü. Az indonéz önkormányzatok 70 százaléka jó eredményt tudott elérni, és csupán 12 százalékuk tudott elérni nagyon jó eredményt.
A kutatási változóink körében korrelációs vizsgálatot is tudtunk végezni. Az eredmény a 3. táblázatban látható.

\section{Paneladatok regressziós elemzése}

A paneladatok regressziós elemzését minden önkormányzat vonatkozásában elkészítettük, majd kerületi és városi önkormányzatokra bontottuk a megfigyeléseket. A modellünk legjobb becslése az összes megfigyelés véletlen hatása. Összesen csak két független változót találtunk, amely jelentős pozitív hatással van a helyi önkormányzat igazgatási teljesítményére: a kockázatelemzés, valamint az információ és kommunikáció. Az eredmények azt bebizonyítják, hogy a kontrollkörnyezet nincs jelentős hatással a helyi önkormányzatok igaz- 


\section{VÁLTOZÓK KÖZÖTTI KORRELÁCIÓK}

\begin{tabular}{|c|c|c|c|c|c|c|c|c|c|c|c|c|}
\hline Változók & (1) & (2) & (3) & (4) & (5) & (6) & (7) & (8) & (9) & (10) & (11) & (12) \\
\hline (1) $\mathrm{LGAP}_{i, t}$ & 1,000 & & & & & & & & & & & \\
\hline (2) CO_ENV & 0,247 & 1,000 & & & & & & & & & & \\
\hline (3) RISK ${ }_{i, t}$ & 0,246 & 0,538 & 1,000 & & & & & & & & & \\
\hline (4) CO_ACTIV & 0,245 & 0,877 & 0,488 & 1,000 & & & & & & & & \\
\hline (5) INFO $_{i, t}$ & 0,260 & 0,767 & 0,517 & 0,727 & 1,000 & & & & & & & \\
\hline (6) $\mathrm{MONI}_{i, t}$ & 0,207 & 0,727 & 0,563 & 0,691 & 0,731 & 1,000 & & & & & & \\
\hline (7) LGASSET $_{i, t}$ & 0,307 & 0,157 & 0,194 & 0,146 & 0,141 & 0,136 & 1,000 & & & & & \\
\hline (8) LGREV $_{i, t}$ & 0,334 & 0,119 & 0,150 & 0,105 & 0,139 & 0,117 & 0,792 & 1,000 & & & & \\
\hline (9) LGEXPEND & 0,375 & 0,079 & 0,161 & 0,063 & 0,121 & 0,090 & 0,805 & 0,954 & 1,000 & & & \\
\hline (10) $\mathrm{LGPOP}_{i, t}$ & 0,415 & 0,188 & 0,152 & 0,208 & 0,185 & 0,118 & 0,620 & 0,820 & 0,809 & 1,000 & & \\
\hline (11) $\mathrm{LGCOM}_{i, t}$ & 0,033 & 0,062 & 0,022 & 0,068 & 0,078 & 0,077 & 0,136 & 0,206 & 0,194 & 0,228 & 1,000 & \\
\hline (12) LGGEO $_{i t}$ & 0,395 & 0,134 & 0,144 & 0,159 & 0,175 & 0,107 & 0,407 & 0,569 & 0,568 & 0,603 & 0,183 & 1,000 \\
\hline
\end{tabular}

Forrás: saját szerkesztés

gatási teljesítményére, de a hatás pozitív és jelentős a városi önkormányzatok vizsgálatában. A kontrolltevékenységek ugyanilyen kevés eredménnyel bírnak, de a hatás negatív a városi önkormányzatok körében. Mindeközben a monitoringnak nincs jelentős hatása az önkormányzatok igazgatási teljesítményére. A paneladatok regressziós eredménye a 4. táblázatban látható:

A kontrollkörnyezetnek összességében nincs jelentős hatása. Ezen eredménnyel összhangban a kontrolltevékenységeknek sincs jelentős hatása az önkormányzatok igazgatási teljesítményére. Az eredmények talán azért nem szignifikánsok, mert a kontrollkörnyezet és kontrolltevékenységek nem optimálisan lettek végrehajtva. A kontrollkörnyezetet és a kontrolltevékenységeket adminisztratív módon létrehozták, de a megvalósítást nem úgy optimalizálták, hogy az lényeges hatással le- gyen az önkormányzatok igazgatási teljesítményére. Érdekes eredményre jutottunk a városi önkormányzat vizsgálatakor. A kontrollkörnyezet pozitív hatással van, míg a kontrolltevékenységek negatív hatással vannak a teljesítményre. A motiváló kontrolltevékenységek fokozzák a belső kontrollrendszer egészének a hatékonyságát (Yurniwati, Rizaldi, 2015). Továbbá fokozzák a jobb teljesítmény lehetőségét a jobb integritásnak és etikának, a kompetencia melletti elköteleződésnek, az alkalmassá tevő vezetésnek, a szervezeti felépítésnek és szakmai munkakapcsolatoknak köszönhetöen (Rubino et al., 2017). Azonban a túlzott kontrolltevékenységek túl szoros felügyeletet eredményeznek, ami eredménytelenséget okozhat mind a költség, mind az eljárások szempontjából (Crouch, 2012). A kontrolltevékenységeknek arányosnak (COSO, 2013) és nem túlzónak kell lenniük. A túlzott kont- 


\section{HIPOTÉZISVIZSGÁLAT A PANELADATOK REGRESSZIÓJÁVAL}

\begin{tabular}{|c|c|c|c|}
\hline Ftiggó & (1) & (2) & (3) \\
\hline $\operatorname{LGAP}_{i, t}$ & Minden önkormányzat & Kerületi önkormányzat & Városi önkormányzat \\
\hline CO_ENV ${ }_{i, t}$ & $\begin{array}{l}0,0534 \\
(0,164)\end{array}$ & $\begin{array}{c}0,0132 \\
(0,184)\end{array}$ & $\begin{array}{c}0,635^{\star} \\
(0,376)\end{array}$ \\
\hline $\operatorname{RISK}_{i, t}$ & $\begin{array}{l}0,191^{\star *} \\
(0,092)\end{array}$ & $\begin{array}{c}0,176^{\star} \\
(0,105)\end{array}$ & $\begin{array}{c}0,285 \\
(0,200)\end{array}$ \\
\hline CO_ACTIV $_{i, t}$ & $\begin{array}{l}-0,205 \\
(0,182)\end{array}$ & $\begin{array}{l}-0,137 \\
(0,206)\end{array}$ & $\begin{array}{c}-0,905^{\star *} \\
(0,389)\end{array}$ \\
\hline $\mathrm{INFO}_{i, t}$ & $\begin{array}{c}0,493^{*} \\
(0,274)\end{array}$ & $\begin{array}{c}0,508^{\star} \\
(0,307)\end{array}$ & $\begin{array}{c}0,242 \\
(0,605)\end{array}$ \\
\hline $\mathrm{MONI}_{i, t}$ & $\begin{array}{c}0,112 \\
(0,174)\end{array}$ & $\begin{array}{r}0,0602 \\
(0,197)\end{array}$ & $\begin{array}{c}0,201 \\
(0,369)\end{array}$ \\
\hline LN_LGASSET $_{i, t}$ & $\begin{array}{r}-0,0420 \\
(0,044)\end{array}$ & $\begin{array}{r}-0,0357 \\
(0,054)\end{array}$ & $\begin{array}{r}0,0617 \\
(0,081)\end{array}$ \\
\hline LN_LGREV $_{i, t}$ & $\begin{array}{l}-0,328^{\star \star *} \\
(0,086)\end{array}$ & $\begin{array}{l}-0,292^{\star \star \star} \\
(0,090)\end{array}$ & $\begin{array}{c}-0,724^{\star *} \\
(0,353)\end{array}$ \\
\hline LN_LGEXPEND & $\begin{array}{l}0,443^{\star \star \star} \\
(0,077)\end{array}$ & $\begin{array}{l}0,431^{\star \star \star} \\
(0,081)\end{array}$ & $\begin{array}{l}0,751^{\star *} \\
(0,316)\end{array}$ \\
\hline LN_LGPOP ${ }_{i, t}$ & $\begin{array}{l}0,133^{\star \star \star} \\
(0,028)\end{array}$ & $\begin{array}{l}0,148^{\star \star \star} \\
(0,031)\end{array}$ & $\begin{array}{c}0,005 \\
(0,073)\end{array}$ \\
\hline $\operatorname{LGCOM}_{i, t}$ & $\begin{array}{l}-0,001^{\star * \star} \\
(0,000)\end{array}$ & $\begin{array}{c}-0,001^{\star \star} \\
(0,000)\end{array}$ & $\begin{array}{l}-0,001 \\
(0,001)\end{array}$ \\
\hline $\mathrm{LGGEO}_{i, t}$ & $\begin{array}{l}0,241^{\star \star \star} \\
(0,048)\end{array}$ & $\begin{array}{l}0,199^{\star \star \star} \\
(0,061)\end{array}$ & $\begin{array}{l}0,302^{\star \star \star} \\
0,069\end{array}$ \\
\hline $\operatorname{LGTYPE}_{i, t}$ & $\begin{array}{l}0,217^{\star \star \star} \\
(0,046)\end{array}$ & & \\
\hline Konstans & $\begin{array}{c}-0,262 \\
(1,247)\end{array}$ & $\begin{array}{c}-1,327 \\
(1,486)\end{array}$ & $\begin{array}{c}1,042 \\
(2,706)\end{array}$ \\
\hline Megfigyelések száma & 1524 & 1245 & 279 \\
\hline Önkormányzatok száma & 508 & 415 & 93 \\
\hline R-négyzet & 0,279 & 0,239 & 0,241 \\
\hline Chi-négyzet & 356,166 & 237,421 & 60,986 \\
\hline Prob > Chi2 & 0,000 & 0,000 & 0,000 \\
\hline
\end{tabular}

Megjegyzés: A koefficiens szignifikáns *** esetén az 1\%-0s, ** esetén az 5\%-0S, * esetén a 10\%-0s szinten.

Forrás: saját szerkesztés 
rolltevékenységek gátat emelhetnek, amely akadályozza az önkormányzatok igazgatási folyamatait a rugalmatlanság miatt, és így a teljesítmény gyengül.

A kockázatértékelésre vonatkozó megállapítás arra utal, hogy a nagyobb kockázatértékelési képesség javít az önkormányzatok igazgatási teljesítményén. Az eredményünk egybeesik az általunk megfogalmazott hipotézissel. Kockázatértékelést úgy kell végrehajtani, hogy a szervezetnek ne legyenek hiányosságai a kockázatok azonosítása, értékelése és kezelése során (Jones, 2008). A kockázatkezelés valóban fontos (Dabbagoglu, 2012) és elválaszthatatlan részévé válik a jó kormányzás elérésének a közszférában (Wardhani et al., 2017). Shanmugam et al. (2012) szerint egy szervezetben felmerülő bármilyen potenciális kockázatot megfelelően kell kezelni. Így a szervezeti tevékenységek a lehető legjobban hajthatók végre. Ezen eredmény alapján a kockázatértékelés is fontos az önkormányzatoknál az elszámoltathatóság fenntartásához, főként a törvény által előírt megfelelő igazgatási teljesítmény elérése érdekében.

$\mathrm{Az}$ is kiderült, hogy az információ és kommunikáció az önkormányzatok igazgatási teljesítményének erős meghatározó eleme, magas együtthatóval. Ez az eredmény arra utal, hogy az információ és kommunikáció az önkormányzatoknál és az önkormányzatok között a helyi kormányzás fontos részévé vált (Lee, Lio, 2016), főként az informatikai technológiák segítségével (Odendaal, 2003). Az indonéz kormányzati szektorban az informatikát e-kormányzással is alkalmazzák (Nulhusna, Sandhyaduhita, Hidayanto, Phusavat, 2017), ami segíti a kormányzati programok megvalósítását. Az információ és a kommunikáció támogatja a kormányzati programokat a tervezéstől, a megvalósításon át az értékelésig, így ezt kihasználva az önkormányzatok is magasabb szintű igazgatási teljesítményt érhetnek el.
Általánosságban, a monitoring fontos a belső kontrollrendszerekben, fóként a technológia segítségével, a belső kontrollfolyamatok hatékonyságának fokozásával és így a megfelelőség biztosításával (Masli, Peters, Richardson, Manuel Sanchez, 2010). Azonban a monitoringnak nincs jelentős hatása az önkormányzatok igazgatási teljesítményére. Ugyanezt az eredményt kaptuk az összes önkormányzatra, a kerületi és a városi önkormányzatokra vonatkozóan egyaránt. Ez a nem szignifikáns eredmény azért adódhatott, mert az önkormányzatok kifejezetten gyengék a monitoring területén (Jaffar, AbdulShukor, 2016). Így a monitoring kevésbé jelentős tényező a belső kontrollrendszerben az indonéz önkormányzatok igazgatási teljesítményének meghatározásakor. Mindazonáltal a monitoring változatlanul fontos része a belső kontrollrendszernek, amelyet a kormánynak folyamatosan javítania kell a belső kontrollrendszer hatékonysága érdekében (Jurnali, Siti-Nabiha, 2015).

Mindeközben a kontrollváltozókkal végzett vizsgálatunk azt mutatja, hogy az önkormányzatok bevételének negatív hatása van, míg a kiadások pozitívan hatnak az igazgatási teljesítményükre. Egyrészt a bevételszerzésre való túlzott összpontosítás nem illik az önkormányzatokhoz, mivel az önkormányzatok - mint közszolgák - kötelesek közszolgáltatást stb. nyújtani. Másrészről a magasabb kiadás támogathatja a kormányzati programok megvalósítását az igazgatási teljesítmény javításához. Az önkormányzatok összetettsége szintén negatív hatással bír, mivel a túl sok munkaegység sok adminisztratív folyamatot követel, amely hatással van az emberi erőforrásra. Továbbá az önkormányzat lakosságszáma pozitív hatású, mivel a fejlettebb önkormányzatok nagyobb népességgel bírnak, fóként a nagyvárosokban, például Tangerangban, Bekasiban, Bogorban, Bandungban, Dzsakartában, Semarangban, Surabaya-ban stb. 


\section{KÖVETKEZTETÉSEK}

Tanulmányunk feltárja, hogy az indonéz önkormányzatok igazgatási teljesítménye 20172019-ben nem teljesíti a Belügyminisztérium 2015-ben megfogalmazott stratégiai tervének elvárásait. Még mindig sok önkormányzat bír közepes és alacsony szintű igazgatási teljesítménnyel. Empirikus bizonyítékot nyújtunk arra vonatkozóan, hogy a belső kontrollrendszer hozzájárul az önkormányzatok igazgatási teljesítményéhez, ahol a kontrollkörnyezet, a kockázatelemzés, valamint az információ és kommunikáció pozitívan hatnak az önkormányzatok igazgatási teljesítményére.
Megállapításaink alapján arra bátorítjuk a BPKP-t, hogy folyamatosan törekedjen az önkormányzatok belső kontrollrendszereinek javítására a képzések és fejlesztési programok maximalizálása révén. Ezért az önkormányzatok belső kontrollrendszere optimálisan megvalósítható annak érdekében, hogy az önkormányzatok igazgatási teljesítménye megfelelően elszámoltatható legyen. Kutatásunk mélyebb betekintést nyújt a belső kontrollrendszerbe és az igazgatási teljesítménybe a többi ország részére, amely alkalmazza a COSO koncepcióját a belső kontrollrendszer fejlesztése során Ázsiában, Európában, Amerikában, Ausztráliában és Afrikában.

\section{JEGYZETEK}

1 2018. évi 118-8840 számú belügyminiszteri határozat a nemzeti teljesítményértékelés meghatározásáról és az önkormányzati igazgatás állapotáról

2 2015. évi 54. számú belügyminiszteri rendelet a Belügyminisztérium 2015-2019-es stratégiai tervéről

3 A kormányzati belső kontrollrendszerről szóló 2008. évi 60. számú kormányrendelet
4 2009. évi 73. számú belügyminiszteri rendelet az LGAPE kézikönyv előírásairól

5 A Pénzügyi és Fejlesztési Felügyelet vezetőjének 2016. évi 4. számú rendelete a kormányzati belső kontrollrendszer értékelésére és stratégiafejlődésére vonatkozó iránymutatásokról

6 A pénzügyi és fejlesztési felügyeleti ügynökség vezetőjének 2016. évi 4. számú rendelete a kormányzati belső ellenőrzési rendszer értékelésére és stratégiafejlődésére vonatkozó iránymutatásokról

\section{IRODALOM}

Adiputra, I. M.P., Utama, S., Rossieta, H. (2018). Transparency of Local Government in Indonesia. [Indonézia helyi kormányzatának átláthatósága.] Asian Journal of Accounting Research, 3(1), pp. 123-138, https://doi.org/10.1108/ajar-07-2018-0019

Aikins, S. K. (2011). An Examination of Government Internal Audits' Role in Improving Fi- nancial Performance. [A kormányzati belső kontrollok szerepének vizsgálata a pénzügyi teljesítmény javításában.] Public Finance and Management, 11(4), pp. 306-337, http://dx.doi.org/10.1108/17506200710779521

Al-Thuneibat, A. A., Al-Rehaily, A. S., Basodan, Y. A. (2015). The Impact of Internal 
Control Requirements on Profitability of Saudi Shareholding Companies. [A belső kontrollkövetelmények hatása a szaúdi részvénytársaságok jövedelmezőségére.] International Journal of Commerce and Management, 25(2), pp. 196-217, https://doi.org/10.1108/IJCOMA-04-2013-0033

Arifin, T., Trinugroho, I., Prabowo, M. A., Sutaryo, S., Muhtar, M. (2015). Local Governance and Corruption: Evidence from Indonesia. [Helyi kormányzás és korrupció: Bizonyítékok Indonéziából.] Corporate Ownership and Control, 12(4CONT1), pp. 194-199, https://doi.org/10.22495/cocv12i4c1p3

Báger G. (2011). Corruption Risk in Public Administration. [Korrupciós kockázatok a közigazgatásban.] Public Finance Quarterly, [Pénzügyi Szemle] 56(1), 44-57. oldal

Beneder M., Szenténé, K., Béres, D. (2014). Internal Controls in Local Governments. [Államháztartási belső kontrollok] Public Finance Quarterly, [Pénzügyi Szemle] 59(3), 296-309. oldal

Crouch, T. (2012). Reducing Excessive Controls. [A túlzott kontrollok csökkentése.] EDPACS: The EDP Audit, Control, and Security Newsletter, 46(5), pp. 11-13, https://doi.org/10.1080/07366981.2012.731832

Dabbagoglu, K. (2012). Fraud in Businesses and Internal Control System. [Csalás a vállalkozásokban és a belső kontrollrendszer.] Journal of Modern Accounting and Auditing, Vol. 8, pp. 983-989

Dalimunthe, D. M. J. F., Fadli, I. M. (2015). A Study on the Impact of Government Complexity and Regional Government's Size on Human Development Index in North Sumatera, Indonesia. [Tanulmány a kormányzat összetettségének és a regionális kormányzat méretének az emberi fejlettségi indexére gyakorolt hatásáról Észak-Sumaterában, In- donéziában.] European Journal of Accounting Auditing and Finance Research, 3(1), pp. 1-19, https://doi.org/10.1377/hlthaff.2013.0625

GYÜrRE L. (2012). The Role of Systematic Internal Control and Audit in Reducing Management Risk at Hungarian Local Governments. [A szisztematikus belső kontroll és audit szerepe a magyar önkormányzatokban jelenlévő kockázatok csökkentésében.] Public Finance Quarterly, [Pénzügyi Szemle] 57(2), 173-183. oldal

Hillison, W., Pacini, C., Sinason, D. (1999). The Internal Auditor as Fraud-Buster. Managerial Auditing Journal, 14(7), pp. 351-363, https://doi.org/10.1108/02686909910289849

Jaffar, R., Abdul-Shukor, Z. (2016). The Role of Monitoring Mechanisms Towards Company's Performance. [Az ellenőrző mechanizmusok szerepe a vállalat teljesítményére.] Journal of Accounting in Emerging Economies, 6(4), pp. 408-428, https://doi.org/10.1108/jaee-05-2014-0021

Jones, M. J. (2008). Internal Control, Accountability and Corporate Governance. [Elszámoltathatóság és vállalatirányítás.] Accounting, Auditing \& Accountability Journal, 21(7), pp. 10521075 ,

https://doi.org/10.1108/09513570810907474

Jurnali, T., Siti-Nabiha, A. K. (2015). Performance Management System for Local Government: The Indonesian Experience. [Teljesítménymenedzsment-rendszer az önkormányzatok számára: Az indonéz tapasztalat.] Global Business Review, https://doi.org/10.1177/0972150915569923

Kiabel, D. (2012). Internal Auditing and Performance of Government Enterprises: A Nigerian Study. [Belső audit és kormányzati vállalatok teljesítménye: nigériai tanulmány.] Global Journal of Management and Business Research, 12(6), pp. $1-20$ 
Koutoupis, A. G. (2012). Importing International Corporate Governance Codes in Greek Publicly Listed Enterprises: A Case Study Analysis. [Nemzetközi vállalatirányítási kódok importálása a görög nyilvánosan jegyzett vállalatokban: Esettanulmány, elemzés.] International Journal of Organizational Analysis, 20(4), pp. 447-463, https://doi.org/10.1108/19348831211268634

Lee, M. H., Lio, M. C. (2016). The Impact of Information and Communication Technology on Public Governance and Corruption in China. $[\mathrm{Az}$ információs és kommunikációs technológia hatása a kormányzásra és a korrupcióra Kínában.] Information Development, 32(2), pp. 127-141, https://doi.org/10.1177/0266666914529293

Lestari, W., Azwardi, A., Siddik, S. (2019). Can Internal Control Prevent Fraud in Managing Village Funds? [A belső kontroll megakadályozhatja a csalásokat a falualapok kezelésében?] Accounting and Finance, 4(86)), pp. 112-118, https://doi.org/10.33146/2307-9878-2019-4(86)-112-118

Liu, J., Lin, B. (2012). Government Auditing and Corruption control: Evidence from China's Provincial Panel Data. [Kormányzati ellenőrzés és korrupcióellenőrzés: Bizonyíték a kínai tartományi elem adataiból.] China Journal of Accounting Research, 5(2), pp. 163-186, https://doi.org/10.1016/j.cjar.2012.01.002

Manzila, E. E. W., ZÉGhal, D. (2016). Content Analysis of Board Reports on Corporate Governance, Internal Controls and Risk Management: Evidence from France. [A vállalatirányításról, a belső kontrollról és a kockázatkezelésről szóló igazgatósági jelentések tartalomelemzése: Bizonyítékok Franciaországból.] Journal of Applied Business Research, 32(3), pp. 637-646, https://doi.org/10.19030/jabr.v32i3.9668

Masli, A., Peters, G. E., Richardson, V. J., Manuel Sanchez, J. (2010). Examining The
Potential Benefits of Internal Control Monitoring Technology. [A belső kontroll monitoring technológia lehetséges előnyeinek vizsgálata.] Accounting Review, 85(3), pp. 1001-1034, https://doi.org/10.2308/accr.2010.85.3.1001

Meluy, C. (2011). Local Government Indebtedness and Debt Management in Switzerland. [Helyi önkormányzatok eladósodottsága és adósságkezelése Svájcban.] Public Finance Quarterly, [Pénzügyi Szemle], 57(2), 164-172. oldal

Naser, S. S. A., Al Shobaki, M. J., Ammar, T. M. (2017). Impact of Communication and Information on the Internal Control Environment in Palestinian Universities. [A kommunikáció és az információ hatása a palesztin egyetemek belső kontrollkörnyezetére.] International Journal of Hybrid Information Technology, 10(11), pp. 41-60, https://doi.org/10.14257/ijhit.2017.10.11.05

Nulhusna, R., Sandhyaduhita, P. I., Hidayanto, A. N., Phusavat, K. (2017). The Relation of E-Government Quality on Public Trust and Its Impact on Public Participation. [Az elektronikus kormányzás minőségének kapcsolata a közbizalomhoz, és hatása a nyilvánosság részvételére.] Transforming Government: People, Process and Policy, 11(3), pp. 393-418, https://doi.org/10.1108/TG-01-2017-0004

OdendaAl, N. (2003). Information and Communication Technology and Local Governance: Understanding the Difference between Cities in Developed and Emerging Economies. [Információs és kommunikációs technológia és helyi kormányzás: A városok közötti különbség megértése a fejlett és a feltörekvő gazdaságokban.] Computers, Environment and Urban Systems, 27(6), pp. 585-607, https://doi.org/10.1016/S0198-9715(03)00016-4

Petrakaki, D., Hayes, N., Introna, L. (2009). Narrowing Down Accountability Through Performance Monitoring Technology: E-Government in 
Greece. [Az elszámoltathatóság szűkítése a teljesítményfigyelési technológia révén: e-kormányzat Görögországban.] Qualitative Research in Accounting \& Management, 6(3), pp. 160-179, https://doi.org/10.1108/11766090910973911

Rakhman, F. (2019). Budget Implementation in a Risky Environment: Evidence from the Indonesian Public Sector. [Költségvetési végrehajtás kockázatos környezetben: bizonyítékok az indonéz közszférából.] Asian Review of Accounting, 27(2), pp. 162-176, https://doi.org/10.1108/ARA-01-2018-0020

Rácz T. A., Tóтн B. (2021). Fiscal Distress of Hungarian Local Governments in the Light of the Debt Consolidation and the Reorganisation of the Municipal System. [A hazai önkormányzatok pénzügyi zavarai az adósságkonszolidáció és az önkormányzati rendszer reorganizációjának tükrében.] Public Finance Quarterly, [Pénzügyi Szemle], 66(1), 91-111. oldal, https://doi.org/10.35551/PFQ_2021_1_5

Rendon, J. M., Rendon, R. G. (2016). Procurement Fraud in the US Department of Defense. [Beszerzési csalás az Egyesült Államok Védelmi Minisztériumában.] Managerial Auditing Journal, 31(6/7), pp. 748-767,

https://doi.org/10.1108/maj-11-2015-1267

Rubino, M., Vitolla, F., Garzoni, A. (2017). The Impact of an IT Governance Framework on the Internal Control Environment. [Az IT irányítási keretrendszer hatása a belső kontrollkörnyezetre.] Records Management Journal, 27(1), pp. 19-41, https://doi.org/10.1108/RMJ-03-2016-0007

Sari, N., Ghozali, I., Achmad, T. (2017). The Effect of Internal Audit and Internal Control System on Public Accountability: the Emperical Study. [A belső audit és a belső kontrollrendszer hatása a nyilvános elszámoltathatóságra: empirikus tanulmány.] International Journal of Civil Engineering and Technology, 8(9), pp. 157-166
Shanmugam, J. K., Нaat, M. H., Ali, A. (2012). An Exploratory Study of Internal Control and Fraud Prevention Measures in SMEs. [A kkv-k belső kontrollja és csalásmegelőzési intézkedéseinek feltáró tanulmánya.] International Journal of Business Research and Managemen, 3(2), pp. 90-99

Sutaryo, S., Sinaga, D. (2018). Government Internal Control System Maturity: The Role of Internal Guidance and External Control of Local Government in Indonesia. [A kormány belső kontrollrendszerének érettsége: az Indonéziában működő helyi kormányzat belső irányításának és külső ellenörzésének szerepe.] Jurnal Akuntansi Dan Investasi, 19(1), pp. 24-35,

https://doi.org/10.18196/jai.190189

Sutopo, B., Sutaryo, Christian, Y. (2017). Empirical Study of the Determinants on Audit Reporting Timeliness: Evidence from Indonesia. [Empirikus tanulmány a meghatározó tényezőkről az ellenőrzési jelentések időszerűségéről: bizonyítékok Indonéziából.] International Journal of Trade and Global Markets, 10(4), pp. 303-313, https://doi.org/10.1504/IJTGM.2017.090272

Sutopo, B., Wulandari, T. R., Adiati, A. K., Saputra, D. A. (2017). E-Government, Audit Opinion, and Performance of Local Government Administration in Indonesia. [E-kormányzat, ellenőrzési vélemény és az önkormányzati igazgatás teljesítménye Indonéziában.] Australasian Accounting, Business and Finance Journal, 11(4), pp. 6-22, https://doi.org/10.14453/aabf.v11i4.2

Suyono, E., Hariyanto, E. (2012). Relationship between Internal Control, Internal Audit, and Organization Commitment with Good Governance: Indonesian Case. [A belső kontroll, a belső audit és a jó kormányzással való elkötelezettség kapcsolata: indonéz eset.] China-USA Business Review, 11(9), pp. 1237-1245,

https://doi.org/10.17265/1537-1514/2012.09.006 
UrbaniK, V. (2016). Making internal control a priority in local government. [A belső kontroll fontossá tétele az önkormányzatokban.] The Journal of Government Financial Management, 65(3), pp. 20-25

Utama, F. R., Evana, E., Gamayuni, R. R. (2019). The Effect of Local Government Characteristics on Performance of Local Government Administration. [Az önkormányzati jellemzők hatása az önkormányzati igazgatás teljesítményére.] International Research Journal of Business Studies, 12(2), pp. 197-208, https://doi.org/10.21632/irjbs.12.2.197-208

Wardhani, R., Rossieta, H., Martani, D. (2017). Good Governance and the Impact of Government Spending on Performance of Local Government in
Indonesia. [Jó kormányzás és a kormányzati kiadások hatása az indonéz helyi önkormányzatok teljesítményére.] International Journal of Public Sector Performance Management, 3(1), pp. 77-102, https://doi.org/10.1504/IJPSPM.2017.082503

Yurniwati, Rizaldi, A. (2015). Control Environment Analysis at Government Internal Control System: Indonesia Case. [Ellenőrzési környezet elemzése a kormány belső kontrollrendszerében Indonézia esetében.] Procedia - Social and Behavioral Sciences, 211(September), pp. 844-850, https://doi.org/10.1016/j.sbspro.2015.11.111

COSO (2013). Internal Control Integrated Framework Executive Summary. New York: COSO 